\title{
FORMULASI GEL PENGHARUM RUANGAN MENGGUNAKAN KARAGENAN DAN XANTHAN GUM DENGAN MINYAK KOPI SEBAGAI PEWANGI DAN MINYAK NILAM SEBAGAI FIKSATIF
}

\section{FORMULATION OFAIR FRESHENER GEL WITH CARRAGEENAN AND XANTHAN GUM AS GELLING AGENT, COFFEE OIL AS FRAGRANCE AND PATCHOULI OIL AS BINDER}

\author{
Rulia Meilina ${ }^{1^{*}}$, Fhasnia ${ }^{2}$ \\ ${ }^{\text {ab }}$ Fakultas Ilmu Kesehatan, Universitas Ubudiyah Indonesia \\ *Koresponding Penulis: rulia.meilina@uui.ac.id ; fasnia98@gmail.com
}

\begin{abstract}
Abstrak
Gel pengharum ruangan salah satu bentuk pengharum ruangan yang digunakan meredam bau taksedap di dalam ruangan. Kelebihan gel pengharum ruangan adalah pengharum yang dihasilkan memiliki kekuatan wangi yang stabil dan ketahanan wangi yang lama sesuai kebutuhan. Tujuan penelitian ini adalah untuk mengetahui pengaruh perbedaan konsentrasi minyak nilam pada formulasi sediaaan. Metode penelitian ini adalah ekpremental laboratorium dengan prosedur memvariasikan formula minyak nilam (F1:1\%; F2:0,5\%; F3:0,24\%; F4:0,25; F5:0\%) sebagai pengikat dengan penambahan karagenan dan xhantan gum sebagai kompenen pembentuk gel dan minyak kopi sebagai bahan pewangi, selanjutnya dilakukan pengujian penguapan zat cair dan pengujian ketahanan wangi selama 4 minggu pada 3 suhu ruangan yaitu ruang diberi kipas angin, ruang diberi $\mathrm{AC}$ dan ruangan biasa (suhu kamar). Hasil penelitian ini menunjukkan bahwa Formulasi sediaan gel pengharum ruangan yang baik didapat pada formula F3 dengan konsentrasi minyak nilam $0,24 \%$.

Kata kunci: Gel pengharum, minyak nilam, minyak kopi, karagenna, xhantan gum
\end{abstract}

\section{Abstract}

Air freshener gel is a form of air freshener that is used to reduce bad odors in the room. The advantages of air freshener gel are the fragrances produced have a stable fragrance strength and long fragrance resistance as needed. The purpose of this study was to determine the effect of differences in patchouli oil concentrations on the available formulations. This research method is a laboratory experiment with the procedure of varying the patchouli oil formula (F1: 1\%; F2: 0.5\%; F3: 0.24\%; F4: 0.25; F5: 0\%) as a binder with the addition of carrageenan and xanthan. gum as a gel-forming component and coffee oil as a fragrance, then testing the evaporation of liquid substances and testing for fragrance resistance for 4 weeks at 3 room temperatures, namely the room is given a fan, the room is given air conditioning and the room is normal (room temperature). The results of this study indicated that the good air freshener gel formulation was obtained in the F3 formula with $0.24 \%$ patchouli oil.

keywords: air freshener gel, patchouli oil, coffee oil, carrageenan, xanthan gum 


\section{PENDAHULUN}

Pengharum ruangan merupakan produk rumah tangga yang dapat mengeluarkan bahan kimia yang dikandungnya ke udara dan dihirup oleh konsumen yang bertujuan untuk meredam bau tak sedap di dalam ruangan sehingga membuat ruangan terasa nyaman (Hutagaol, 2017). Produk pengharum ruangan dapat dibuat dalam berbagai bentuk sediaan, antara lain cair, semi padat dan padat. Bentuk gel membuat pelepasan zat pewangi atau pengharum semakin lambat. Gel yang baik adalah yang memiliki kekuatan gel tinggi dan sineresis rendah sehingga gel pengharum ruangan yang dihasilkan akan memiliki kekuatan wangi yang stabil dan ketahanan wangi yang lama sesuai kebutuhan (Kariza, 2015).

Gel pengharum ruangan menggunakan karagenan dan Xanthan gum sebagai komponen pembentuk gel. Karagenan yang dijadikan sebagai bahan pembuat gel pengharum ruangan berfungsi melepaskan minyak aroma secara perlahan. Xanthan gum merupakan pengentaldan penstabil terbaik karena memiliki sifat fisikokimia terbaik dibandingkan polisakarida lainnya Kombinasi karagenan dan xanthan gum dapat menghasilkan matrik gel pengharum ruangan secara optimal (Kariza, 2015).

Zat pengikat umumnya berasal dari nabati golongan gum, resin, lilin atau beberapa jenis minyak atsiri yang bertitik didih tinggi misalnya minyak akar wangi, minyak kayu cendana dan minyak nilam (Kaya, 2018). Minyak nilam dalam industri farmasi digunakan sebagai fiksatif (zat pengikat) kemapuan mengikat dari minyak nilam belum dapat tergantikan sampai saat ini minyak nilam memiliki komponen titik didih tinggi (Faizal, dkk., 2018).

Tujuan adanya penambahan minyak nilam pada formula adalah untuk mencegah pelepasan wangi yang terlalu cepat (Sofiani, dkk., 2018). Bahan pewangi dari alam dapat berasal dari buah, bunga, batang dan biji. Aroma dari Biji kopi saat ini banyak diminati masyarakat sebagai pewangi runagan, karena kopi memliki aroma khas dan jantan serta membuat penikmat aroma menjadi rilex (Ambarita, 2019).

\section{METODE PENELITIAN}

\section{Bahan}


Journal of Healthcare Technology and Medicine Vol. 6 No. 2 Oktober 2020

Universitas Ubudiyah Indonesia

e-ISSN : 2615-109X

Bahan yang digunakan pada penelitian ini adalah karagenan, xanthan gum,minyak kopi, minyak nilam, propilen glikol, natrium benzoat dan aquadest.

\section{Pembuatan Gel Pengharum Ruangan}

Alat dan bahan yang digunakan disiapkan. Semua bahan ditimbang (Tabel 1.1). Gelas beker dikalibrasi $50 \mathrm{~mL}$ kemudian dipanaskan aquadest hingga suhu $75^{\circ} \mathrm{C}$. Karagenan, xanthan gum dan natrium benzoat dimasukkan ke dalam gelas beker kemudian ditambahkan akuades yang telah dipanaskan, dipindahkan gelas beker ke penangas air agar suhu tetap stabil dan diaduk cepat hingga larut dan homogen. Gelas beker yang berisi campuran karagenan, xanthan gum dan sodium benzoat dipindahkan dari penangas air, agar suhunya menurun hingga $65^{\circ} \mathrm{C}$ sambil terus diaduk dengan cepat. Setelah suhu mencapai $65^{\circ} \mathrm{C}$, ditambahkan propilen glikol, aduk hingga homogeny. Minyak nilam dan minyak kopi ditambahkan ke dalam campuran tersebut, diaduk cepat hingga homogen dan ditambahkan sisa akuades sampai batas kalibrasi, aduk hingga homogen. Campuran tersebut dituang ke dalam cetakan, dibiarkan pada suhu ruangan hingga mengeras (Meilina dan Afriana, 2019).

Tabel 1.1. Formula gel pengharum ruangan dengan memvariasikan Konsentrasi minyak nilam (50 gram)

\begin{tabular}{lccccc}
\hline \multicolumn{1}{c}{ Bahan } & F1 & F2 & F3 & F4 & F5 \\
\hline Karagenan (g) & 1,6 & 1,6 & 1,6 & 1,6 & 1,6 \\
Xanthan Gum (g) & 0,4 & 0,4 & 0,4 & 0,4 & 0,4 \\
Minyak kopi (g) & 2 & 2 & 2 & 2 & 2 \\
Minyak nilam (g) & 0,50 & 0,25 & 0,12 & 0,10 & - \\
Natrium Benzoat (g) & 0,10 & 0,10 & 0,10 & 0,10 & 0,10 \\
Propilen glikol (g) & 5,00 & 5,00 & 5,00 & 5,00 & 5,00 \\
Aquadest (ml) & 42,85 & 42,85 & 42,85 & 42,85 & 42,85 \\
\hline
\end{tabular}

Keterangan : F1 : Formula minyak nilam $1 \%$; F2 : Formula minyak nilam 0,50\%; F3 : Formula minyak nilam $0,24 \%$; F4 : Formula minyak nilam $0,20 \%$; F5 : Formula minyak nilam $0 \%$.

\section{Uji Penguapan Zat Cair}

Uji penguapan zat cair dilakukan dengan cara menimbang setiap bobot fomula gel pengharum ruangan selama satu bulan, ditimbang setiap minggu sekali. Sediaan diletakan di 4 ruangan yaitu ruangan $\mathrm{AC}$, ruangan disertai kipas angin, dan ruangan bersuhu kamar (Andini, 
Journal of Healthcare Technology and Medicine Vol. 6 No. 2 Oktober 2020

Universitas Ubudiyah Indonesia

e-ISSN : 2615-109X

2019). Setelah diperoleh besar penurunan bobot gel setiap minggunya dan penurunan bobot setalah 4 minggu penyimpanan. Dengan menghitung selisih bobot gel pada awal $\left(\mathrm{M}_{0}\right)$ dengan bobot gel pada saat penimbangan $\left(\mathrm{M}_{\mathrm{n}}\right)$ maka diperoleh penurunan bobot gel pengharum ruangan (Tambun., 2017).

Persen $(\%)$ total penguapan zat cair $=\frac{(M 0-M 4)}{M 0} X 100 \%$

Perhitungan persentase bobot gel sisa:

Persen bobot gel sisa $=\frac{\text { bobot gel minggu ke-n(Mn) }}{\text { bobot gel minggu-0 }(M 0)} \times 100 \%$

\section{Uji Ketahanan Wangi Gel}

Pengujian ketahanan wangi dinilai oleh 25 penalis dengan untuk mengetahui ketahanan produk gel pengharum ruangan selama sebulan penggunaan dengan variasi 5 Formula yaitu F1, F2, F3, F4 dan F5. Uji kehanan wangi dilakukan dengan cara mencium gel pengharum ruangan sebanyak 2-3 kali, sediaan formula diletakkan dengan jarak $20 \mathrm{~cm}$ dari hidung dan wangi dicium dengan mengibas-ngibaskan tangan kearah hidung dari sediaan gel yang telah disimpan atau ditempatkan di 3 ruang yaitu ruangan ber AC, ruangan diberi kipas angin dan ruangan bersuhu kamar dengan ukuran $3 \times 3-4 \times 4$. Nilai ketahanan wangi dilihat dari lembar kuisioner dengan menulis skala 1 sampai 5 dimana 1 (sangat tidak wangi), 2 .(agak kurang wangi), 3 (agak wangi), 4 (wangi) dan 5 (sangat wangi). Data yang telah diperoleh dari kuisinoner ditabulasi dan ditentukan nilainya untuk setiap sediaan dengan mencari hasil rerata pada setiap penalis (Andini., 2019).

\section{ANALISIS DATA}

Hasil uji ketahanan wangi diperoleh menggunakan rumus statistik. Data yang diperoleh dari kuisioner ditabulasi dan ditentukan nilai kesukaannya untuk setiap sediaan dengan mencari hasil rerata pada setiap penalis pada tingkat kepercayaan 95\%. Menghitung interval nilai mutu rerata dari setiap penalis digunakan rumus sebagai berikut:

- $\bar{x}=\frac{\sum_{\mathrm{i}}^{\mathrm{n}}=\mathrm{Xi}}{\mathrm{n}}$

- $\mathrm{S}^{2}=\frac{\sum_{i}^{n}(X i-X)^{2}}{n}$

- $\mathrm{S}=\sqrt{S^{2}}$

- $P(\bar{X}-(1,96 . S / \sqrt{n}) \leq \mu \leq(\bar{X}+(1,96 . S / \sqrt{n}) \cong 95$ 
Journal of Healthcare Technology and Medicine Vol. 6 No. 2 Oktober 2020

Universitas Ubudiyah Indonesia

e-ISSN : 2615-109X

Keterangan : N:Banyak penelis; $\mathrm{S}^{2}$ :Keseragaman nilai kesukaan; 1,96:Koefesien standar deviasi pada taraf 95\%; $\bar{X}$ :Nilai kesukaan rata-rata; Xi: Nilai dari panelis ke I, dimana $\mathrm{I}=1,2,3, \ldots . . \mathrm{n} ; \mathrm{S}$ : Simpangan baku nilai kesukaan; $\mathrm{P} \quad$ : Tingkat kepercayaan; $\mu$ : Rentang nilai.

\section{HASIL DAN PEMBAHASAN}

\section{Hasil Uji Penguapan Zat Cair}

Uji penguapan zat cair dilakukan untuk mengetahui bobot gel yang tersisa yang telah disimpan selama 4 minggu pada 3 ruangan yaitu ruangan suhu kamar, ruangan diberi kipas angin dan ruangan AC. Pengujian ini dilakukan dengan cara menimbang tiap minggu gel yang telah disimpan pada 3 suhu ruangan tersebut. Berat produk yang hilang merupakan minyak atsiri dan air yang menguap dari gel. Oleh sebab itu, menurut (Nababan dan Hans, 2018) semakin besar bobot yang sisa maka semakin besar ketahanan wangi gel tersebut hal ini disebabkan karena sedikit minyak atsiri dan air yang menguap. Hasil persentase bobot sisa gel pengharum ruangan kamar dapat dilihat pada Tabel 1.2

Tabel 1.2 Persentase bobot sisa gel pengharum ruangan pada suhu kamar.

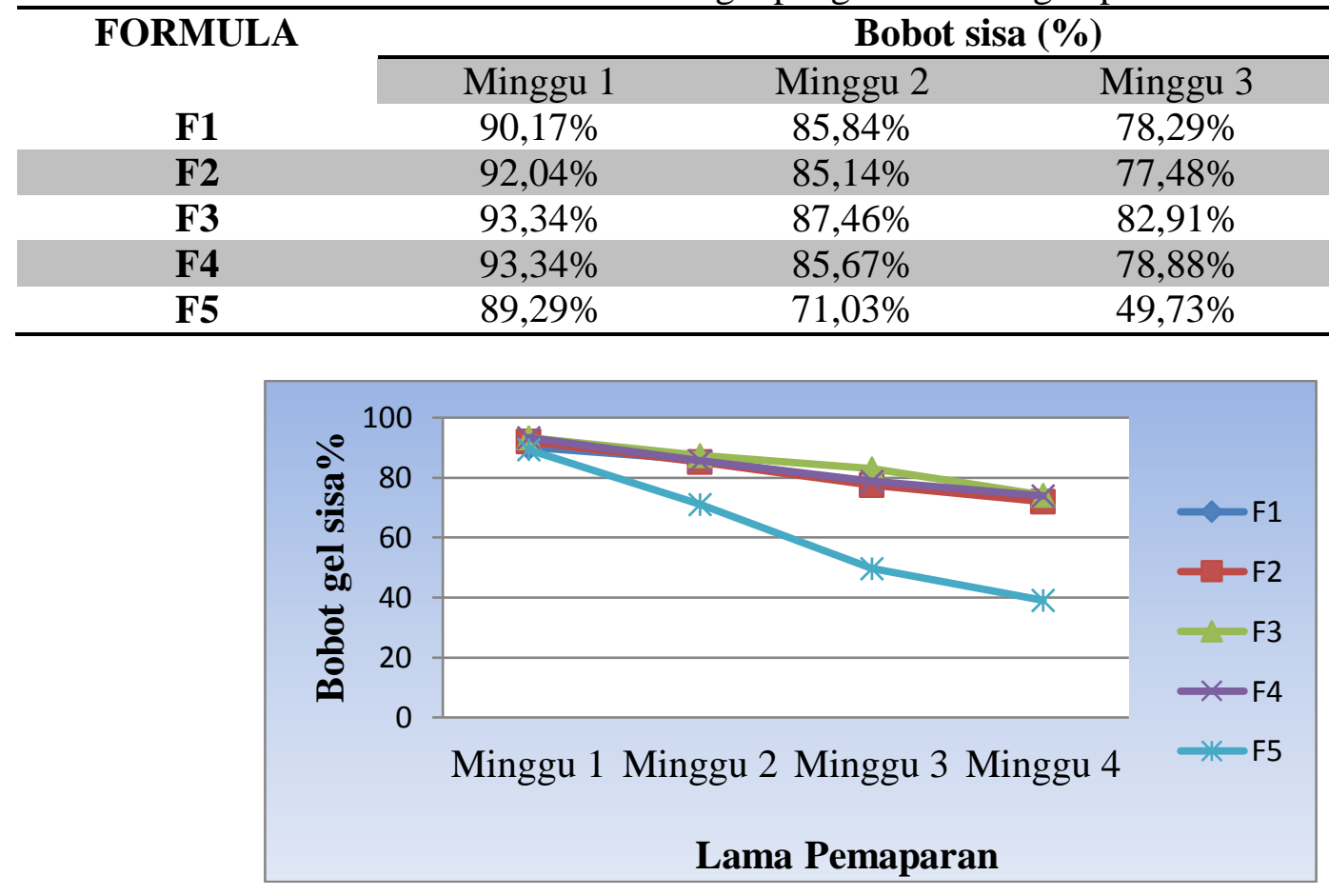

Gambar 1.1 Grafik persentase bobot gel sisa pengharum ruangan selama pemaparan pada ruangan suhu kamar. 
Journal of Healthcare Technology and Medicine Vol. 6 No. 2 Oktober 2020

Universitas Ubudiyah Indonesia

e-ISSN : 2615-109X

Formula terbaik perenstase bobot gel sisa pengharum ruangan pada suhu kamar adalah formula F3 dengan konsentrasi minyak nilam 0,24\% karena memiliki nilai persentase 74,12\% dimana nilai yang paling besar dari pada nilai persentase formula lainnya. Sedangkan nilai terkecil terdapat pada formula F5 yang memiliki nilai peresntase bobot gel sisa 39,70\% karena pada formula ini tidak terdapat minyak nilam. Menurut (Ismuyanto, ddk., 2013) tingginya minyak nilam yang ditambahkan ke dalam gel pengharum ruangan tidak disertai dengan semakin rendahnya pengurangaran masa gel. Hal ini berarti bahwa gel mempunyai kemampuan maksimum untuk menerima minyak atsiri. Hasil persentase bobot sisa gel pengharum ruangan AC dapat dilihat pada tabel 1.3

Tabel 1.2 Persentase bobot sisa gel pengharum ruangan pada suhu AC

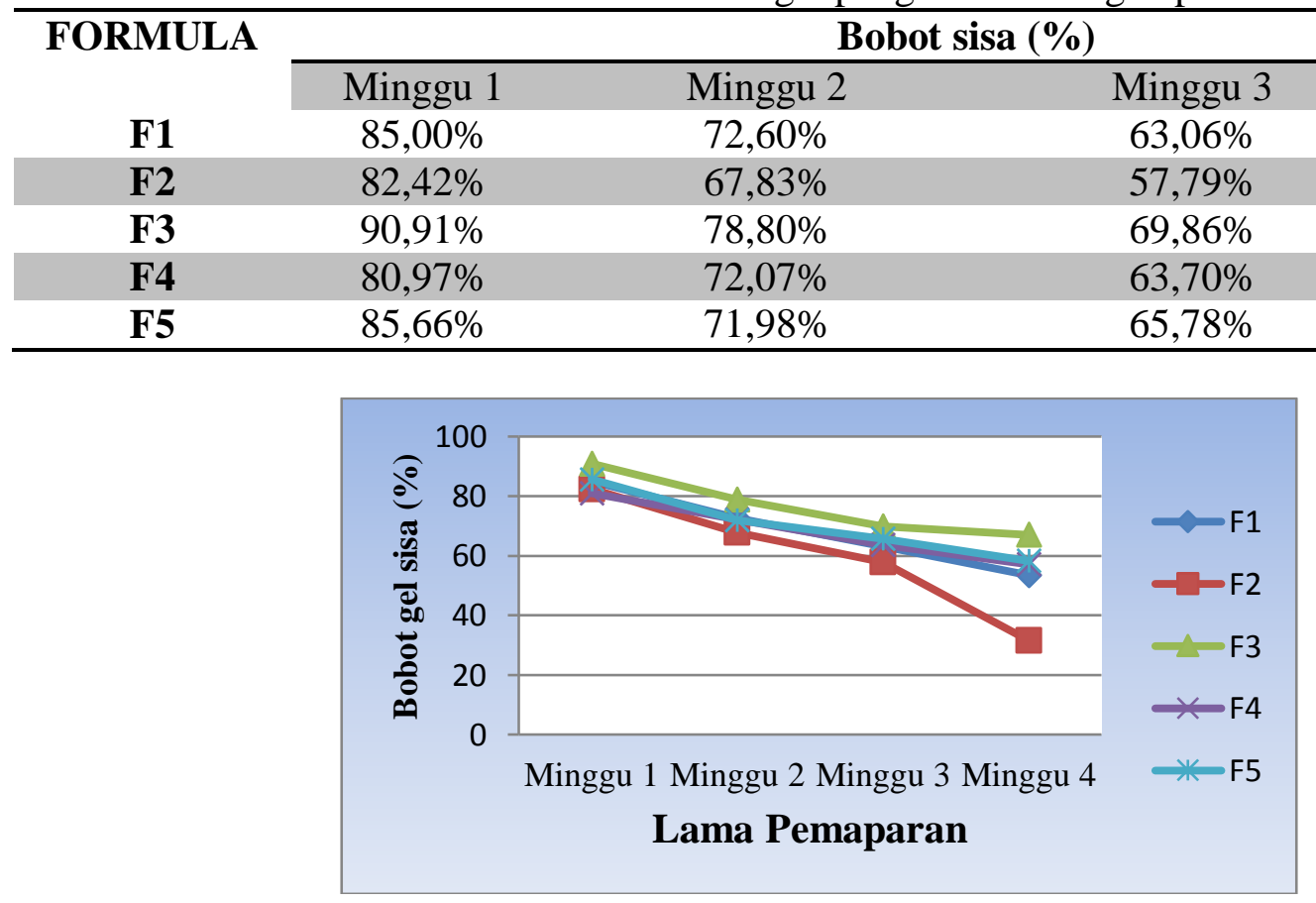

Gambar 1.2 Grafik persentase bobot gel sisa pengharum ruangan selama pemaparan pada ruangan suhu AC.

Berdasarkan gambar 1.2 dapat disimpulkan formula terbaik pada pemaparan suhu AC adalah Formula F3 dengan minyak nilam 1\% sebagai pengikat karena memiliki nilai bobot gel sisa terbesar dari yang lainnnya yaitu 66,99\%. Sedangkan nilai bobot gel sisa terkecil adalah formula F2 yaitu 31,56 dengan minyak nilam $0,20 \%$. Semakin besar sisa bobot gel maka semakin bagus kuliatas gel pengharum ruangan. Semakin tinggi suhu dan semakin rendah kelembaban maka 
Journal of Healthcare Technology and Medicine Vol. 6 No. 2 Oktober 2020

Universitas Ubudiyah Indonesia

e-ISSN : 2615-109X

tingkat penguapan zat cair pada gel pengharum ruangan akan semakin besar. Hal ini mengakibatkan tingkat peuangapan pewangi dan air bebas yang terkandung dalam gel pengharum ruangan akan semakin besar dan sebaliknya. Menurut (Ismuyanto, ddk., 2013) tingginya minyak nilam yang ditambahkan ke dalam gel pengharum ruangan tidak disertai dengan semakin rendahnya pengurangaran masa gel. Hal ini berarti bahwa gel mempunyai kemampuan maksimum untuk menerima minyak atsiri.

Tabel 1.4 Persentase bobot gel pengharum ruangan pada suhu Kipas Angin

\begin{tabular}{ccccc}
\hline FORMULA & \multicolumn{4}{c}{ Bobot sisa (\%) } \\
\cline { 2 - 5 } F1 & Minggu 1 & Minggu 2 & Minggu 3 & Minggu 4 \\
F2 & $92,84 \%$ & $73,17 \%$ & $62,83 \%$ & $61,29 \%$ \\
F3 & $75,52 \%$ & $60,20 \%$ & $41,68 \%$ & $31,84 \%$ \\
F4 & $94,01 \%$ & $86,78 \%$ & $76,80 \%$ & $69,71 \%$ \\
F5 & $85,33 \%$ & $67,78 \%$ & $67,19 \%$ & $56,19 \%$ \\
\hline
\end{tabular}

Berdasarkan Gambar 1.3 dapat disimpulkan formula terbaik pada pemaparan suhu kipas angin adalah Formula F3 dengan minyak nilam 1\% sebagai pengikat karena memiliki nilai bobot gel sisa terbesar dari yang lainnnya yaitu $69,71 \%$. Sedangkan nilai bobot gel sisa terkecil adalah formula F2 yaitu 31,84 dengan minyak nilam 0,20\%. Semakin besar sisa bobot gel maka semakin bagus kuliatas gel pengharum ruangan. Semakin tinggi suhu dan semakin rendah kelembaban maka tingkat penguapan zat cair pada gel pengharum ruangan akan semakin besar. Hal ini mengakibatkan tingkat peuangapan pewangi dan air bebas yang terkandung dalam gel pengharum ruangan akan semakin besar dan sebaliknya. Menurut (Ismuyanto, ddk., 2013) tingginya minyak nilam yang ditambahkan ke dalam gel pengharum ruangan tidak disertai dengan semakin rendahnya pengurangan masa gel. Hal ini berarti bahwa gel mempunyai kemampuan maksimum untuk menerima minyak atsiri. 


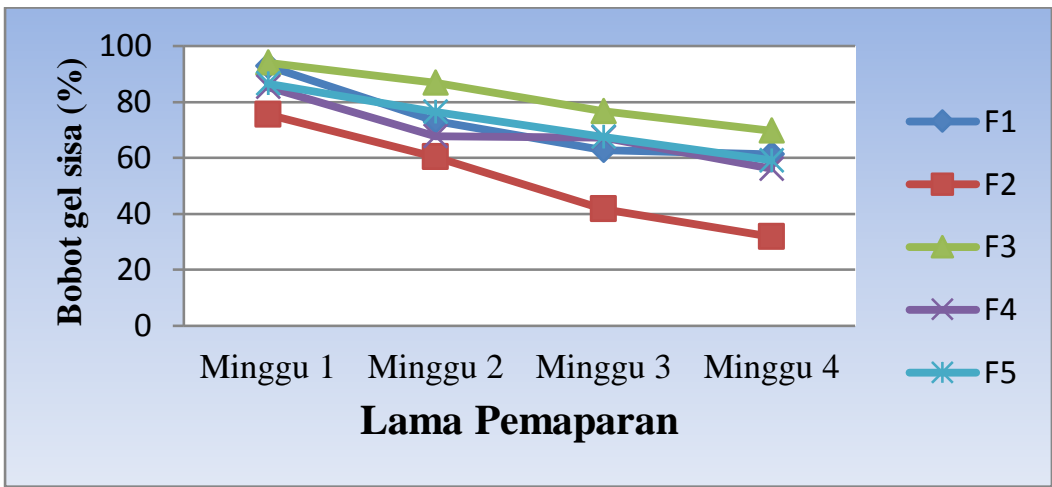

Gambar 1.3 Grafik persentase bobot gel sisa pengharum ruangan selama pemaparan pada ruangan suhu kipas Angin.

Tabel 1.5 Total persentase penguapan zat cair

\begin{tabular}{cccccc}
\hline Ruangan & \multicolumn{5}{c}{ Total penguapan zat cair (\%) } \\
\cline { 2 - 6 } Uji & F1 & F2 & F3 & F4 & F5 \\
Suhu & 27,98 & 28 & 25,82 & 26,08 & 60,92 \\
Kamar & & & & & \\
$\begin{array}{c}\text { Kipas } \\
\text { Angin }\end{array}$ & 48,08 & 68,43 & 33 & 40,74 & 41,75 \\
AC & 38,70 & 68,15 & 30,28 & 43,80 & 40,81 \\
\hline
\end{tabular}

Menurut (Sofiani, dkk., 2018) penambahan minyak nilam ke dalam formula memberikan hasil sineresis yang lebih rendah dibandingkan dengan tanpa penambahan minyak nilam. Hal ini disebabkan karena minyak nilam sebagai bahan fiksatif mampu mengikat wangi dan air komponen air yang terjerap didalam matriks gel sehingga hanya sedikit air yang tidak terikat dari struktur matriks gel yang komplek. Penambahan minyak nilam yang dicampurkan dengan pewangi pada formula membuat matriks gel memiliki susunan yang rapat sehingga struktur gel menjadi lebih padat. Hal tersebut yang mempengaruhi total penguapan zat cair dan persen bobot sisa gel. Semakin besar nilai bobot gel sisa maka semakin baik dan sebaliknya karena tinggat penguapannya zat cairnya semakin sedikit.

Namun teknik pengadukan juga mempengaruhi susut bobot, karena semakin homogen suatu larutan maka kestabilan gel akan lebih baik dan penguapan dapat dihambat. Selain itu juga disebabkan oleh suhu penyimpanan yang mengakibatkan air lebih cepat menguap, sirkulasi udara dalam ruangan, dan ukuran ruangan. Sirkulasi udara dan ukuran ruangan mempengaruhi perbedaan gradient konsentrasi minyak dan air didalam gel dengan ruangan. Ruangan dengan sirkulasi udara yang tinggi dan terbuka serta ukuran ruangan yang lebih luas membuat gradient konsentrasi 
Journal of Healthcare Technology and Medicine Vol. 6 No. 2 Oktober 2020

Universitas Ubudiyah Indonesia

e-ISSN : 2615-109X

minyak yang lebih besar sehingga minyak lebih cepat menguap (Aksari dan Jeni 208). Menurut (Sitepu,2018) persentase susut bobot pada produk pengharum ruangan juga dapat dipengaruhi oleh beberapa faktor yaitu suhu, komposisi bahan pembentuk gel dan komposisi bahan pewangi dan pengikat.

\section{Hasil Uji Ketahanan Wangi}

Uji ketahanan wangi dilakukan untuk mengetahui seberapa lama gel pengharum dapat melepaskan wangi sampai wanginya habis atau tidak tercium lagi.

Tabel 1.5 Uji Ketahanan Ruang (Suhu Kamar)

\begin{tabular}{ccccc}
\hline FORMULA & MINGGU 1 & MINGGU 2 & MINGGU 3 & MINGGU 4 \\
\hline F1 & $2,60-3,15$ & $2,58-2,84$ & $2,43-2,84$ & $1,84-2,15$ \\
F2 & $2,73-3,34$ & $2,80-3,10$ & $2,60-3,07$ & $1,98-2,41$ \\
F3 & $3,76-4,07$ & $3,75-4,00$ & $3,52-4,15$ & $3,04-3,34$ \\
F4 & $3,76-4,07$ & $3,70-3,97$ & $3,64-3,95$ & $2,88-3,19$ \\
F5 & $2,87-3,24$ & $2,48-2,95$ & $2,04-4,08$ & $2,04-2,35$ \\
\hline
\end{tabular}

Berdasrkan tabel diatas ketahanan wangi pemaparan pada ruang suhu kamar selama 4 minggu F1 memiliki ketahanan 1,84-2,15 untuk nilai ketahanan diambil nilai terkecil dan dibulatkan menjadi 2 (kurang suka). F2 memiliki ketahanan 1,98-2,41 untuk nilai ketahanan diambil nilai terkecil dan dibulatkan menjadi 2 (kurang suka), F3 memiliki ketahanan 3,04-3,34 untuk nilai ketahanan diambil nilai terkecil dan dibulatkan 3(cukup suka). F4 memiliki 2,88-3,19 untuk nilai ketahanan diambil nilai terkecil dan dibulatkan 3 (cukup suka). F5 memiliki ketahanan 2,04-2,35 untuk nilai ketahanan diambil nilai terkecil dan dibulatkan menjadi 2 (kurang suka).

Tabel 1.6 Uji Ketahanan Suhu Ruang AC

\begin{tabular}{ccccc}
\hline FORMULA & MINGGU 1 & MINGGU 2 & MINGGU 3 & MINGGU 4 \\
\hline F1 & $2,65-3,18$ & $2,70-3,13$ & $2,43-3,00$ & $1,81-2,18$ \\
F2 & $2,85-3,26$ & $2,90-4,89$ & $2,71-3,28$ & $1,85-2,46$ \\
F3 & $3,16-3,98$ & $3,15-4,07$ & $3,60-3,99$ & $2,91-3,24$ \\
F4 & $3,61-3,98$ & $3,15-4,07$ & $3,66-4,01$ & $2,52-3,07$ \\
F5 & $3,07-3,64$ & $2,86-3,10$ & $2,07-2,40$ & $1,94-2,21$ \\
\hline
\end{tabular}

Ketahanan wangi pemaparan pada ruang suhu AC selama 4 minggu F1 memiliki ketahanan 1,81-2,18 untuk nilai ketahanan diambil nilai terkecil dan dibulatkan menjadi 2 (kurang suka). F2 memiliki ketahanan 1,85-2,46 untuk nilai ketahanan diambil nilai terkecil dan dibulatkan menjadi 2 (kurang suka), F3 memiliki ketahanan 2,91-3,24 untuk nilai ketahanan diambil nilai 
Journal of Healthcare Technology and Medicine Vol. 6 No. 2 Oktober 2020

Universitas Ubudiyah Indonesia

e-ISSN : 2615-109X

terkecil dan dibulatkan 3(cukup suka). F4 memiliki 2,52-3,07 untuk nilai ketahanan diambil nilai terkecil dan dibulatkan 3 (cukup suka). F5 memiliki ketahanan 1,94-2,21 untuk nilai ketahanan diambil nilai terkecil dan dibulatkan menjadi 2 (kurang suka).

Tabel 1.7 Uji Ketahanan Suhu Kipas Angin

\begin{tabular}{ccrrc}
\hline FORMULA & MINGGU 1 & \multicolumn{1}{c}{ MINGGU 2 } & MINGGU 3 & MINGGU 4 \\
\hline F1 & $2,72-3,27$ & $2,53-2,98$ & $2,30-2,73$ & $1,88-2,19$ \\
F2 & $2,92-3,47$ & $2,60-3,15$ & $2,44-2,91$ & $2,04-2,43$ \\
F3 & $3,74-4,09$ & $3,83-4,08$ & $3,75-4,00$ & $2,95-3,28$ \\
F4 & $3,74-4,09$ & $3,76-4,07$ & $3,75-4,00$ & $2,68-3,07$ \\
F5 & $2,75-3,32$ & $2,53-3,06$ & $1,99-2,24$ & $1,99-2,75$ \\
\hline
\end{tabular}

Ketahanan wangi pemaparan pada ruang suhu kipas angin selama 4 minggu F1 memiliki ketahanan 1,88-2,19 untuk nilai ketahanan diambil nilai terkecil dan dibulatkan menjadi 2 (kurang suka). F2 memiliki ketahanan 2,04-2,43untuk nilai ketahanan diambil nilai terkecil dan dibulatkan menjadi 2 (kurang suka), F3 memiliki ketahanan 2,95-3,28 untuk nilai ketahanan diambil nilai terkecil dan dibulatkan 3 (cukup suka). F4 memiliki 2,68-3,07untuk nilai ketahanan diambil nilai terkecil dan dibulatkan 3 (cukup suka). F5 memiliki ketahanan 1,99-2,75untuk nilai ketahanan diambil nilai terkecil dan dibulatkan menjadi 2 (kurang suka).

Menurut (Sitepu, 2018) ketahanan wangi yang masih dalam baik adalah diatas nilai 2 yaitu sangat wangi sampai kurang wangi. Dapat disimpulkan bahwa formula baik pada 3 ruang yaitu pada formula F3 dan F4 karena memiliki nilai ketahanan 3 (cukup suka). Namun penguapan bahan juga mempengaruhi ketahanan, waktu penyimpanan dimana semakin lama waktu penyimpanan maka semakin banyak waktu bahan yang menguap sehingga ketahanan wangi produk juga dipengaruhi oleh sisa bobot gel dan penguapan zat cair. Semakin kecil bobot yang hilang atau semakin besar bobot yang tersisa berarti semakin sedikit minyak atsiri dan air yang telah menguap, artinya semakin besar ketahanan wangi dari produk gel tersebut.

Ketahanan wangi juga dipengaruhi oleh penambahan minyak nilam sebagai pengikat, karena zat pengikat dapat menghambat atau mengurangi kecepan dari penguapan zat pewangi. Komposisi bahan pengikat dan pewangi juga mempengaruhi ketahanan. Rendahnya konsentrasi bahan pewangi dan tinggi konsentrasi bahan pengikat yang digunakan membuat bau yang dihasilkan didominasikan oleh bahan pengikat sehingga tertutupi bau dari pewangi. Sebaliknya, jika konsentrasi bahan pengikat rendah maka bau yang dihasilkan dapat bertahan lama dan bau 
Journal of Healthcare Technology and Medicine Vol. 6 No. 2 Oktober 2020

Universitas Ubudiyah Indonesia

e-ISSN : 2615-109X

dari pewangi dapat tersebar dari dengan baik. Tujuan adanya penambahan minyak nilam untuk mencegah pelepasan wangi yang teralu cepat. (Sofiani, dkk., 2018)

Ukuran ruangan juga mempengaruhi pelepasan wangi dan zat cair pada gel sehingga memberi aroma pada ruang yang ditempati. Ruangan yang besar akan mempersulit pelepasan wangi ke udara untuk memberi keharuman pada ruangan tersebut sebaliknya jika ruangan kecil akan mudah bagi gel untuk melepaskan pewangi ke udara untuk memberi keharuman pada ruangan tersebut (Kaya, 2018).

Dalam Kaya, 2018 (De-Ross, 2003) terdapat dua faktor utama yang mengontrol nilai pelepasan bahan pewangi dari suatu produk pengharum yaitu, kemampuan melepaskan pewangi dari produk dasar (faktor termodinamik) dan kemampuan/ daya tahan transfer massa dari produk ke udara. Dalam Kaya, 2018 (Taqi et al, 2011) pengemasan produk juga dapat mempengaruhi disamping dapat memperpanjang masa simpan juga dapat mengontrol transfer masa antara produk yang dikemas dengan lingkungan sekitar.

\section{KESIMPULAN}

Formulasi sediaan gel pengharum ruangan yang baik didapat pada formula F3 dengan konsentrasi Minyak nilam 0,24\%.

\section{SARAN}

Diharapkan peneliti selanjutnya dapat meneliti formulasi gel pengharum ruangan dengan bahanbahan alam lainnya.

\section{DAFTAR PUSTAKA}

Aksari dan Jeni, N,. 2018. Pembuatan gel pengharum ruangan menggunakan karagenan dan xhantan gum sebagai basis dengan aroma apel dan mminyak akar wangi. Skripsi. Sumatera Utara. Fakultas Farmasi Universitas Sumatera Utara.

Ambarita. R. 2019. Limbah kopi pengharum ruangan. Medan. Fakultas Kehutanan Universitas Sumatra Utara.

Andini, D. 2019. Formulasi gel pengharum ruangan berbasis karagenan dan glukomanan menggunakan minyak atsiri jeruk nipis sebagai pewangi serta minyak atsiri nilam sebagai fiksatif. Surakarta. Universitas Setia Budi.

Faizal, M.M., Ardiansyah .J., dan Muyassroh,. 2018. Pengambilan patchouli alcohol dari minyak nilam menggunakan metode hydro distilation microwave dengan variasi perlakuan bahan dan waktu distilasi. Malang. Teknik Kimia, Institut Teknologi Nasional Malang. 
Hutagaol, R. 2017. Forrmulation ofair Freshener Gel with Carrageenan as Gelling Agent, Lemon Oil as Fragrance and Patchouli Oil as Binder. International Journal of ChemTech Research. Vol.10No.4.

Ismuyanto. B., Agustina. P.D. dan Nirwana. W.D.C. 2013. Karakteristik Gel Pengharum Ruangan dengan Berbagai Grade Patchouli Alhohol dan Konsentrasi Minyak Nilam. Program Studi Teknik Kimia Fakultas Teknik Universitas Brawijaya. Malang.

Kariza, D.A. 2015. Ekstraksi Pektin dari Cincau Hijau (Premna oblongifolia. Merr) untuk Pembuatan Gel Pengharum Ruangan. Skripsi. Semarang. Universitas Negeri Semarang.

Kaya, A.OW. 2018. Pemanfaatan karaginan semi murni sebagai bahan pembentuk gel dalam pembuatan gel dalam gel pengharum ruangan. Ambon. Fakultas perikanan dan ilmu kelautan Universitas Pattimura Ambon.

Meilina. R., Afriana, S. 2019. Efek anti inflamasi gel kacang hijau pada mencit putih (Mus musculus). Journal of Healthcare Technology and Medicine. V01 2, issue 2.

Nababan dan Hans.P. 2018. Formulasi Gel Pengharum Ruangan Menggunakan Basis Campuran Hydoxy Propyl Methyl Cellulose (HPMC) dan Pektin Dengan Minyak Lemon Sebagai Pewangi dan Minyak Akar Wangi Sebagai Fiksatif. Skripsi.

Sitepu. B Dan Renti J. 2018. Formulasi Gel Pengharum Ruangan Menggunakan Karagenan dan Tragakan sebagai Basis, Minyak Jeruk Mania Sebagai Pewangi dan Minyak Nilam sebagai Fiksatif. Fakultas Farmasi Universitas Sumatra Utara. Sumatra Utara.

Sofiani.V., Islam. N.I., dan Chaerunissa.Y.A. 2018. Formula Gel Aromaterapi dengan Basis Karagenan. Fakultas Farmasi Universitas Pjajaran. Bandung.

Tambun, M.U.D,. 2017 Formulasi gel pengharum ruangan menggunakan karagenan dan pektindengan minyak cendana sebagai fiksatif dan minyak kulit kayu manis sebagai pewangi. Skripsi. Medan.

Taqi A, Askar KA., Nagy K, Mutihac L, Stamatin L. 2011. Effect Of Different Concentrastions Of Olive Oil And Oleic Acid On The Mechanical Properties Of Albumen (Egg White) Edible Films. Afric J Biotech. 